\title{
Illocutionary Acts in Panggih Ceremonies in Tegal and Those in Tanjung Morawa
}

\author{
Ratika Astimawati ${ }^{1, *}$ Amrin Saragih ${ }^{2}$ Anni Holila Pulungan ${ }^{3}$ \\ ${ }^{1}$ Post Graduate Program of English Applied Linguistic, Universitas Negeri Medan, Medan, Indonesia \\ ${ }^{2}$ Post Graduate Program of English Applied Linguistic, Universitas Negeri Medan, Medan, Indonesia \\ ${ }^{3}$ Post Graduate Program of English Applied Linguistic, Universitas Negeri Medan, Medan, Indonesia \\ *Corresponding author. Email: Ratika.asti@ymail.com
}

\begin{abstract}
This research aim is to find out the types of illocutionary acts found in panggih ceremonies in Tegal and those in Tanjung Morawa. The research will conduct by using descriptives qualitative design. The data of this research are sentences, phrases, and words that consist of illocutionary acts in panggih ceremonies in Tegal and those in Tanjung Morawa. The data sources are the wedding ceremonies in Tegal and Tanjung Morawa. Two wedding ceremonies will be take in each city, which will be the data sources of this research. Then, the data will analyze by using types of speech acts [1]. The data will be collected by direct observation and video of a wedding ceremony- such a sentence, phrase, and word of pranatacara will be the data of this research. The results of this study were found that there were five types of illocutionary acts in panggih ceremonies. Those were Directive, Assertive, Commissive, Expressive and Declarative.
\end{abstract}

Keywords : speech act, illocutionary act, javanese wedding ceremonies

\section{INTRODUCTION}

Language is a way of human in communication to give an impact and making a good relation. It means that a language is a part of society and social process. Sometime an utterance that we produce has several meaning, it influenced by phrase known as pragmatics. Pragmatics is a branch of linguistics that discusses what includes the structure of language as a means of communication between speakers and listeners.

Pragmatics have several branch those are deixis, implicature, preposition and speech act. Speech act is an action performed in saying something [1]. There are three types of speech acts, they are Locutionary act, Illocutionary act and Perlocutionary act [1]. Illocutionary act classified into five classes, those are declaration, assertive, expressive, directive, and commissive [2]. First declaration is an utterance that change the world. Second, assertive is kind of speech act that give the speaker impact on the truth. Third, expressive is kind of speech act that convey the speaker's psychological attitude toward a situation. Fourth, directive is kind of speech act that used a speaker to command other people to do something. Last, commissive is kind of a speech a by the speaker to make a commitment themselves to actions in the future. Such as; promise, threats, refusing, etc.

Illocutionary act is accomplished utterance with a communicative intention. A speaker may perfom illocutionary act to make a promise, offer, explanation, etc. It also appear in a ritual of wedding ceremony. Indonesia has several ritual in wedding ceremony, such Javanese ritual, Malaynese ritual, Minangkabaunese ritual, Balinese ritual, Sundanese ritual, Banjarnese ritual, Sasaknese ritual and others. Normally, each of these region have a similirity in doing ritual of wedding ceremony. For instance, opening of master ceremony (MC), welcoming speech of MC, main event of wedding ceremony, asking their parents agreement and prayer to start their new journey in life and closing.

Historically, Javanese wedding customs came from the palace. The traditional Javanese wedding procedures, can only be done inside the palace walls or people who are still descendants or servants of the palace, which in Java known as "priyayi". In the past, engagement was intended to ask wheter the woman already has it or not, but now engagement is only a formality as confirmation that the woman has ordered to be married. At this time, it is also very rare for the two 
prospective brides to undergo a secession ceremony. But, it does not mean that the traditional wedding series is just a formality procedure. Until now, there are still many people who are intereste in holding the complete stages of the ritual ceremony of a "tempo doeloe" style weding ceremony.

Wedding ritual in javanese culture has two typical sources coming from Yogyakarta palace and Surakarta palace. Javanese wedding in Tegal did a wedding ceremony same as in Yogyakarta palace just a few ritual that did not use. Javanese wedding in many region have a similarity to the origin of Javanese wedding in Java. Javanese people are separate in many region and they have a community to maintain their culture and language. One of Javanese people that exist at Sumatera are citizen in Tanjung Morawa. The writer interview Mr. Js (a person who has join Pujakesuma) to know the historical background of javanese people in Tanjung Morawa.

He said that in 1997 Javanese people in Tanjung Morawa established a group, named Pujakesuma (Putera Jawa Kelahiran Sumatera). This group was established to carry out social activities and cultural arts activities, for example to preserve kuda lumping or lumping horse and preserve Javanese traditional marriage. At that time, Pujakesuma only for Javanese people who are lived in Aceh into Lampung. Nowdays, they change into FKWJ (Forum Komunikasi Warga Jawa) Javanese citizen comunication community. This forum was formed in 2005, this forum more bigger than Pujakesuma because this community applies to all Javanese people in Indonesia. The FKWJ office for the Sumatera region is on Tanjung Morawa, thus many citizen still maintain a culture of Javanese especially in a wedding ceremony.

Javanese wedding ceremony has many rituals, one of them is Panggih. Panggih is ndaup or the meeting, thus Panggih is the meeting of the bride and the groom in doing many rituals. The bride and the groom were not meet before these rituals started. Panggih ceremonies are a local wisdom for Javanese people. Panggih ceremony is a traditional wedding ceremony when the groom and the bride meet, it is held at the place of the bride. This is held because in its ceremony has an important role according to customary norms. Customs are established rules and include all conceptions of the cultural system of culture to regulate human action in social life [3]. Javanese weddings in Java island may do the wedding ritual based on their parameter. But Javanese wedding in Sumatra island may do a wedding ceremony differently its influence of their culture. These are a Table 1 of ritual panggih ceremonies in both Tegal and Tanjung Morawa.

Table 1. The difference of Panggih Ceremonies in Tegal and Tanjung Morawa

\begin{tabular}{|c|c|c|c|}
\hline $\mathrm{Nu}$. & $\begin{array}{l}\text { List of Panggih } \\
\text { Ceremonies }\end{array}$ & Tegal & $\begin{array}{l}\text { Tanjung } \\
\text { Morawa }\end{array}$ \\
\hline 1 & $\begin{array}{l}\text { Upacara balangan } \\
\text { sedah }\end{array}$ & $\sqrt{ }$ & $\sqrt{ }$ \\
\hline 2 & Upacara wiji dadi & $\sqrt{ }$ & $\sqrt{ }$ \\
\hline 3 & $\begin{array}{l}\text { Upacara sindur } \\
\text { binayang }\end{array}$ & $\sqrt{ }$ & $\sqrt{ }$ \\
\hline 4 & Timbang (pangkon) & $\sqrt{ }$ & - \\
\hline 5 & Upacara tukar kalpika & - & - \\
\hline 6 & $\begin{array}{l}\text { Kacar-kucur } \quad \text { (Tampa } \\
\text { Kaya) }\end{array}$ & $\sqrt{ }$ & - \\
\hline 7 & $\begin{array}{l}\text { Dhaharan } \\
\text { walimah) }\end{array}$ & $\sqrt{ }$ & - \\
\hline 8 & Ujukan tirto wening & $\sqrt{ }$ & - \\
\hline 9 & Upacara mertui & $\sqrt{ }$ & $\sqrt{ }$ \\
\hline 10 & Upacara sungkeman & $\sqrt{ }$ & $\sqrt{ }$ \\
\hline
\end{tabular}

Normally, panggih ceremonies in Java island are upacara balangan sedah "throw a betel", Upacara wiji dadi "stomp an egg", Upacara sindur binayang "the bride and the groom are walking together with their parents", Timbang (pangkon) "weigh the bride and the groom", Upacara tukar kalpika "rings exchange", Kacar-kucur "the groom give a cup of rice and coin", Dhaharan (sekul walimah) "eating together", ujukan tirto wening "drink fresh water", Upacara mertui "inlaw ceremony", and Upacara sungkeman "prayer ceremony". In fact, javanese wedding in Tanjung Morawa are different from Java island. Javanese wedding in Tanjung Morawa did not contain Timbang (Pangkon) "weigh the bride and the groom", kacarkucur (tampa kaya) "the groom give a cup of rice and coin", dhaharan "eating together" and ujukan tirto wening "drink fresh water" in their rounddown. Both in Tegal and Tanjung Morawa did not do upacara tukar kalpika or ring exchange because nowadays they did exchange ring in marriage contract. Thus, there is no ritual of tukar kalpika.

There are many wedding ceremony that are carried out in Javanese wedding ceremony such; Upacara Siraman Pengantin Putra-Putri "a bathing ceremony", Midodaremi "the groom's family comes to the bride's room", Akad Nikah "marriage contract" and Panggih. Panggih ceremonies have several ceremony such as; Upacara Balangan Sedah "throw a betel", Upacara Wiji Dadi "stomp an egg", Upacara Sindur Binayang 
"the bride and the groom are walking together with their parents", Timbang (Pangkon) "weigh the bride and the groom", Upacara Tanem, Upacara Tukar Kalpika "ring exchange", Kacar-Kucur (Tampa Kaya) "the groom give a cup of rice and coin", Kembul Dhahar (Sekul Walimah) "eat", Menghabiskan Dhaharan, Upacara Mertui "in-law ceremony", and Upacara Sungkeman "prayer ceremony" [4].

Javanese wedding in Tanjung Morawa did not do timbang (pangkon), tukar kalpika, kacar-kucur, dhaharan and ujukan tirto wening. The writer interview the pranatacara in Tanjung Morawa especially at Limau Manis village, he said that in fact he knew that there were some rituals that missed it because the family of the bridegroom did not prepare for those rituals. The pranatacara also said that they did not perfom some ritual because to save time. Mostly, javanese at Limau Manis did a many wedding ceremonya such malaynese and javanese rituals. It because one of the bridegroom were from malaynese.

Based on the explanation on the background of the study before, the objective of the research is formulated as in the following:

1. to analyze the types of illocutionary acts found in panggih ceremony in Tegal and Tanjung Morawa.

The research objective is formulated to answer the following problem of the research :

1. what types of illocutionary acts are found in panggih ceremonies in Tegal and those in Tanjung Morawa?

The scope of the research is limited to the types of utterances used in panggih ceremony in Tegal and Tanjung Morawa. It limited to the illocutionary acts used by pranatacara.

\subsection{Illocutionary Act}

Illocutionary acts are a speaker intention in uttering the word, thus it found in panggih ceremonies. There were many linguistic communication used, such: acts of ordering, admitting, asking, reporting, complaining, etc. Illocutionary acts classified into five those are Asserive, Directive, Commissive, Expressive and Declarative [5].

\subsection{Speech Act}

A speech act is an utterance spoken in an actual communication situation. Speech act is the ways in which language can be used [6]. Speech is an action performed of a speaker. Means that utterances has much interpretation depending on how the hearer interprets it.

\subsection{Wedding Ceremony}

Wedding ritual in javanese culture has two typical sources coming from yogyakarta and surakarta palaces. Wedding ceremony was held only for royal families, but nowdays it common to see that common people have their wedding ceremony like royal family does. There are several ritual in doing javanese wedding, those are : nontoni "ceremony that to know who are the bride", melamar "engagement", piningset "give something as a fastener for both the bride and the groom", pasang tarub "yellow coconut decoration", siraman dan midodaremi "bathing and the bride night", akad nikah "marriage contract", pangih "the meeting of the bride and the groom", and ngabekten or sungkeman "asking to pray" [7].

Many ceremony which is carried out in Javanese weddings, those are Upacara Siraman Pengantin PutraPutri, Midodaremi, Akad Nikah and Panggih [4]. In Panggih ceremony itself has several ritual namely; Upacara Balangan Sedah, Upacara Wiji Dadi, Upacara Sindur Binayang, Timbang ( Pangkon) dan Disusul Upacara Tanem, Upacara Tukar Kalpika, Kacar Kucur ( Tampa Kaya ), Kembul Dhahar "Sekul Walimah", Menghabiskan Dhaharan, Upacara Mertui, and Upacara Sungkeman.

Panggih means dhaup or meet, in complete meaning is the traditional ceremony of meeting the bride and the groom [8]. Panggih ceremonies is implemented after akad nikah (for moeslim) or misa nikah (for chirstians). Panggih ceremonies is the main ceremonies for a series of traditional Javanese wedding ceremony.

\subsection{Relevant Studies}

Expressive speech act: the story dewaruci plays work of dalang nartasabda. This research aimed to explain the relevances of expressive illocutionary acts functions revealed in dewaruci story, in the implementation of character education, and to contribute understanding and enrichment to the ragmatics applied to the performing arts object. The worldview for the Javanese is its pragmatics value to reach a state of certain psychics, namely calmness, tranquility, and inner balance. The expressive illocutionary act submitted by the dalang often contain messages, such as moral, spiritual, educational, and enlightenment [9]. 
Ripple Ma'anyam Dayak is an old literary work because tumet a poem performed at the wedding customs Ma'anyan tribes commonly called Wurung Jue andacts of speech commonly used in ripple namely locutions and illocutionary speech act. Riak also has characteristics in common with each stanza ryhme that these ripples consist of four lines with end rhymes a-ba-b. Each array consist of figurative or sampiran, while the content or the exact meaning contained in the third and four lines. WurungJue is a series of events Proces Dayak Customary Marriages Ma'anyan and Lawangan. WurungJue or bird is a symbol of faithful to their spouse. This research used qualitative research. The data is collected from the form of words or pictures instead of numbers. The research data were retrieved through data collection techniques such as observation, interviews and documentation, namely the recording and record ripple used in ceremonies [10].

The types of speech acts used in Mbaba Belo Selambar in Karonese Wedding Ceremony and to know the most dominant types of speech acts used in Mbaba Belo Selambar in Karonese Wedding Ceremony. The subject of this study was Anak Beru in Delitua. That were people who were participated in this event and also as speakers. Inorder to get more valid data, the researcher also interviewed Pengetua Adat as a key informant. He would give more information about Karonese event especially Mbaba Belo Selambar in Wedding Ceremony. Data analysis resulted that: Anak Beru used three types of speech acts in Karonese wedding ceremony those are representative, diretive and expressive; the dominant types of speech acts used by Anak Beru in wedding ceremony is directive; wedding ceremony in Karonese is counted as happinese ceremony Anak Beru used directive because they were mostly talk about suggestion and asking question in this event; and Mbaba Belo Selambar was done because it was time for both families [11].

\section{METHOD}

\subsection{Research Design}

The study conducted by applying descriptive research design. Descriptive qualitative method is the method that emphasized to the meaning and description of certain condition (in certain context) which is used in daily life. Qualitative research has the natural setting as the direct source of data. It means that qualitative research is the study things in their natural settings, attempting to make sense in terms of the meaning people bring to them [12].

\subsection{The data and the Source of Data}

The source data in this study were utterances of the pranatacara in the panggih ceremonies. The data were illocutionary acts found in the utterances of panggih ceremonies.

\subsection{Technique of Data Analysis}

The data had been collected by direct observation then a writer watch a video of wedding ceremony which had a sentence, phrase and word. The source data of this research were wedding ceremonies in Tegal and Tanjung Morawa. The data in a wedding ceremony at Tegal had been collected by watch a video and the data from Tanjung Morawa had been taken by direct observation. These were the procedure that use in the data collection between Tegal and Tanjung Morawa. The data collected by observation, meaning that the observer sat to observe the panggih ceremonies in Tanjung Morawa; but in Tegal, the writer only watch a video which has been recording.

\section{RESULT AND FINDINGS}

\subsection{Types of Illocutionary Acts in Panggih Ceremonies}

The data were analyzed based on the types of ilocutionary act, namely: Assertive, Directive, Commissive, Expressive and Declarative [5]. The following analysis is to describe the types of illocutionary acts in panggih ceremonies in Tegal and Tanjung Morawa. There are five types of illocutionary found in panggih ceremonies. Each types have a various numbers and percentages. The highest was Directive and the lowest was Commissive.

Based on Table 2, it could be seen that there were various data of each pranatacara in Tegal and Tanjung Morawa. Total of illocutionary acts which used by YN was 119 of illocutionary acts, SM was 119 of illocutionary acts, JS was 130 of illocutionary acts, and the last ST was 109 of illocutionary acts. The total from all the pranatacara were 241 illocutionary act of of directive, 133 illocutionary act of assertive, 70 illocutionary act of expressive, 27 illocutionary act of declarative and 6 illocutionary act of commissive. 
Table 2. Data of Pranatacara in Panggih Ceremonies

\begin{tabular}{|c|c|c|c|c|c|c|c|}
\hline $\mathrm{Nu}$ & $\begin{array}{l}\text { Kinds } \\
\text { Of } \\
\text { Illoqutionary } \\
\text { Acts } \\
\text { Of } \\
\text { prame }\end{array}$ & 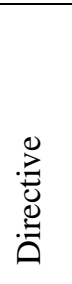 & 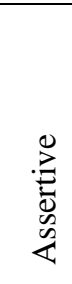 & 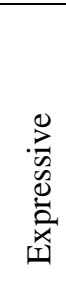 & 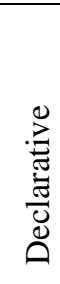 & 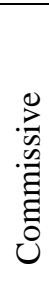 & $\stackrel{\overparen{\Xi}}{0}$ \\
\hline 1 & $\mathrm{YN}$ & 64 & 39 & 10 & 1 & 5 & 119 \\
\hline 2 & SM & 47 & 23 & 34 & 15 & 0 & 119 \\
\hline 3 & JS & 82 & 27 & 14 & 7 & 0 & 130 \\
\hline \multirow[t]{2}{*}{4} & ST & 48 & 44 & 12 & 4 & 1 & 109 \\
\hline & Total & 241 & 133 & 70 & 27 & 6 & 477 \\
\hline
\end{tabular}

After know the result of illocutionary act from those city, then the writer concluded as follows:

Table 3. Percentage of Illocutionary Acts in Panggih ceremonies

\begin{tabular}{clcc}
\hline Nu. & $\begin{array}{c}\text { Kinds of } \\
\text { Illocutionary Acts }\end{array}$ & Numbers & Percentages\% \\
\hline 1 & Directive & 241 & 51 \\
2 & Assertive & 133 & 28 \\
3 & Expressive & 70 & 15 \\
4 & Declarative & 27 & 6 \\
5 & Commissive & 6 & 1 \\
\hline \multicolumn{2}{r}{ Total } & 477 & 100 \\
\hline
\end{tabular}

Based on Table 3, it could be seen that there were 5 types of illocutionary acts namely: Assertive, Directive, Commissive, Expressive, and Declarative in Panggih ceremonies in Tegal and those in Tanjung Morawa. The mostly illocutionary act used is Directive with $51 \%$. Pranatacara used directive in panggih ceremonies both in Tegal and Tanjung Morawa to give a command to the bride and the groom in doing something of each rituals. Assertives was the second, there were 132 utterances out of 477 utterances, with $28 \%$. Expressive was the third, there were 71 utterances out of 477 utterances, with $15 \%$. Declarative was the fourth, there were 27 utterances out of 477 utterances, with $5 \%$. The low percentages of illocutionary acts was commissive, there were 6 utterances out of 477 utterances, with $1 \%$.

\section{CONCLUSION}

Based on the data analysis and the research findings, it is concluded that all the types of illocutionary acts were used pranatacara in panggih ceremonies. They were assertive, directive, commissive, expressive and declarative.
In relations to the conclusions, it is suggested for the next researcher who is interested in wedding ceremonies. The writer assumes that ritual from other wedding ceremonies has many topics that can be observed. They could expand their insight and found the unique side such as the figurative language, a language style, or the difference of javanese wedding in many region. It is advisable for other researchers to conduct the research about illocutionary in wedding ceremonies by providing more data to enrich the analyses of the mostly type of illocutionary act used in other wedding ceremonies. From each ritual of panggih ceremonies learner will get some explanation and new knowledge in doing reasearch of wedding ceremonies. They will get new idea in doing observe as the writer done.

\section{REFERENCES}

[1] Austin. J.L. (1962). How To Do Things With Words. Oxford University Press.

[2] Yule, G. (1996). Pragmatics. New York: Oxford University Press.

[3] Wiranta, I.G. (2002). Antropologi Budaya. Pt. Citra Aditya Bakti. Bandung.

[4] Bangunjiwo, K.J. (2019). Tata Cara Pengantin Jawa: Pranatacara, Rias, Busana, Srana, Sesaji, Ritual-Ritual dan Maknanya. Narasi. Yogyakarta.

[5] Searle, J. R. (1979). Expression and Meaning: Studies in the theory of Speech Act. New York: Cambridge University Press.

[6] Smith, P. W. Hesling. (1991). Speech Act Theory, Discourse Structure and Indirect Speech Act. England:Department of Philosophy. America.

[7] Bratawijaya, T.W. (1985). Upacara Tradisional Masyarakat Jawa. Jakarta: Pustaka Sinar Harapan.

[8] Pringgawidagda, S. 2006. Tata Upacara dan Wicara Pengantin Gaya Yogyakarta. Yogyakarta: Kanisius

[9] Herawati, S.H. (2018). Expressive Speech Act: The Story Dewaruci Plays Work of Dalang Nartasabda.International Journal of Science an Research (IJSR). Vol.7 Issue 2.

[10] Perdana, I. (2016). Speech Acts in Wedding Ceremony Wurung Jue of Dayak Ma'anyan. International Journal of Langauge Education and Culture Review (IJLECR). Vol(2) No. 2. 
[11] Lumbanbatu, I.M.F. (2018). An Analysis of Speech Acts in Mbaba Belo Selambar in Karonese Wedding Ceremony. Jurnal Ilmiah Skylandesa. Vol 2. No. 1

[12] Bogdan, R.C., and Sari, K.B. (1992). Qualitative Research for Education: An Introduction to Theory and Methods. Allyn and Bacon. 